\title{
THE ESTIMATION OF GHG EMISSION COSTS IN ROAD AND AIR TRANSPORT SECTOR: CASE STUDY OF SERBIA
}

\author{
Ivan Ivković, Olja Čokorilo, Snežana Kaplanović \\ Faculty of Transport and Traffic Engineering, \\ University of Belgrade, Serbia \\ Submitted 16 April 2015; resubmitted 31 July 2015; accepted 15 September 2015; \\ published online 11 April 2016
}

\begin{abstract}
The paper gives special attention on long distance passenger transport and specific emissions related to different transport modes, particularly road and air transport sector. The goal of this research is creation and selection of appropriate methodology for modelling the cost estimation of GHG emissions in road and air transport sector for Republic of Serbia as well as the application of the methodology regarding to detailed calculation by transport mode and sub modes. Input data for road transport sector refer to the 2013 and include road and traffic conditions on the road network. Input data for air transport sector are related to the 2014 and international airport 'Nikola Tesla' Belgrade as the main hub point with the highest recorded number of aircraft operations in the Western Balkan countries. The obtained results reveal that, due to realized transport volume, diesel cars have the largest share of the costs of GreenHouse Gas (GHG) emissions within the passenger long distance road transport. Cost estimates of $\mathrm{CO}_{2}$ emissions in the air transport sector shows that A319 aircraft type have the major share in total costs. The reasons are twofold: first, a high level of Landing and Take-Off (LTO) emission factor for $\mathrm{CO}_{2}$ and second, largest number of LTO cycles.
\end{abstract}

Keywords: road transport; air transport; motor vehicle; aircraft; greenhouse gas; air pollutant; emission; cost.

\section{Introduction}

Over the last couple of decades all industry segments have been interested in a negative impact it has on the environment, especially transport industry as the biggest polluter. Road transport has been considered as the largest polluter because of a huge number of vehicles. Nevertheless, air transport takes a special place because of its high altitude movement regimes (Nešić et al. 2015). Since the transport sector is a significant drive force of economic development of each country and that the precondition for that is infrastructure provision, it is important to understand the importance of modal split and environmental preconditions of certain transport mode (Galanis, Eliou 2014; Török 2014; Andrejszki et al. 2014b).

GreenHouse Gas (GHG) emissions of the transport sector (including indirect emissions from electricity generation) increased by almost two and a half times, from $2.9 \mathrm{Gt} \mathrm{CO}_{2}$ eq worldwide in 1970 to $7.1 \mathrm{Gt} \mathrm{CO}_{2}$ eq in 2010 (IEA 2012; JRC/PBL 2013; IPCC 2013). Only two transport modes recorded an increase in the share of total transport sector GHG emissions for the observed period. These are road transport and international aviation. In 2010 the highest share of GHG emissions had road transport, even $72.06 \%$, while international and domestic aviation together recorded a share of $10.62 \%$ (IEA 2012; JRC/PBL 2013; IPCC 2013).

In the EU, that appears as a world leader in the fight against climate change, GHG emissions from the transport sector was less than $1.2 \mathrm{Gt} \mathrm{CO}_{2} \mathrm{eq}$ in 2012. Both, freight and passenger transport significantly contribute to the $\mathrm{CO}_{2}$ emissions. In 2010, freight transport amounted to $42 \%$, while passenger transport accounted for around $58 \%$ of the $\mathrm{CO}_{2}$ eq transport emissions (EEA 2014). The long-distance transport contributes to a major share of global energy use and GHG emissions. This is confirmed by the fact that freight and passenger longdistance transport demand together account for up to $75 \%$ of GHG transport emissions (EEA 2014). Factors that have influence on long distance transport, especially air transport, are economic situation, infrastructure availability, population's growth, migrations, transport

Corresponding author: Olja Čokorilo

E-mail: oljav@sf.bg.ac.rs 
service development, transport price, technological progress and secondary homes. Some of them have already been investigated by (Andrejszki et al. 2014a).

The paper is focused on contemporary methodologies for modelling the cost estimation of GHG emissions in two dominant transport modes related to long distance transportation, road and air transport. Data selection and obtained results are reflecting emissions and external cost of GHG in Serbian transport sector. Serbia is chosen as non EU country with respect to overall traffic flows by crossing corridors (road) and hub airport (international airport 'Nikola Tesla' Belgrade) as the main hub point with the highest recorded number of aircraft operations in the Western Balkan countries. Therefore, proposed research is divided upon following chapters on: literature review - chapter 1; methodology for modelling estimation of GHG emission costs in road and air transport sector - chapter 2; cost estimation of GHG emissions in road and air transport, case study of Serbia - chapter 3 and conclusions.

\section{Literature Review}

In the literature, we can find numerous studies, which deal with assessments and projections of GHG emissions from transport, especially from road transport. What is common to many of these studies is that they reveal that if no action is taken, $\mathrm{CO}_{2}$ emissions will continue to increase and road transport will retain the largest share in the total $\mathrm{CO}_{2}$ emissions from transport. Both, passenger (Peng et al. 2015) and freight road transport (Hao et al. 2015) are analysed in these studies. In addition, in many of these studies authors proposed different mitigation measures and assessed their effectiveness in GHG reduction (Yan, Crookes 2009; Bakker, Huizenga 2010; Kaplanović, Mijailović 2012; Török et al. 2014; ChavezBaeza, Sheinbaum-Pardo 2014).

In order to assess and compare the environmental performance of vehicles, researchers have developed different vehicle environmental rating methodologies. Batista et al. (2015) present several methodologies, which are used in the world. They usually include air pollutants, but some of them also include GHG and noise as impact categories. Bickert et al. (2015) have calculated and compared private costs, as well as emissions and external costs of $\mathrm{CO}_{2} \mathrm{eq}$ in the production and operation phases of small electric and combustion engine vehicles.
Alonso et al. (2014) analysed air transport traffic and $\mathrm{CO}_{2}$ emissions in the $\mathrm{EU}$ countries and found that distances between 500 and $1,000 \mathrm{~km}$ has more $\mathrm{CO}_{2}$ emissions than larger distances. On the other side, Loo et al. (2014) in their study examined the impacts of hubbing activities in air transport on $\mathrm{CO}_{2}$ emissions. They estimated and compared $\mathrm{CO}_{2}$ emissions of two airports, Athens International Airport and the Hong Kong International Airport, at the airport, airspace and flight levels. In order to raise capital from the airline sector to invest in GHG emissions reduction projects Arul (2014) proposed four methodologies to monetize variations in load factor and GHG emissions per passenger-mile of airlines.

According to all the previously mentioned, it is quite clear that special attention must be paid to the assessment of emissions and external costs of GHG in the road and air transport. These data are very important for determining economic policy instruments whose implementation limits the negative impact of road and air transport on the environment in the field of global warming.

\section{Methodology for Modelling Estimation of GHG Emission Costs in Road and Air Transport Sector}

This chapter describes methodology for modelling the cost estimation of GHG emissions in road and air transport sector as two dominant modes in long distance passenger transport. Fig. 1 briefly describes evaluation methodology for road transport considering transport volume on the selected road network.

GHG emissions cost $\left(\mathrm{CO}_{2}, \mathrm{CH}_{4}, \mathrm{~N}_{2} \mathrm{O}\right)$ per year for the whole road network is obtained by summing the costs of GHG emissions by individual road sections according to the formula Eq. (1):

$\left.\operatorname{GHGCOST}=\sum_{k=1(i, j)}^{n} \sum_{(i)} \cdot f_{F C} \cdot E F_{\mathrm{GHG}(i, j)} \cdot \operatorname{UCOST}_{\mathrm{GHG}(j)}\right)_{(k)}[€]$,

where: $i$ - vehicle category (passenger car, bus, light truck, medium truck, heavy truck and articulated truck); $j$ - type of GHG $\left(\mathrm{CO}_{2}, \mathrm{CH}_{4}\right.$ or $\left.\mathrm{N}_{2} \mathrm{O}\right) ; k$ - characteristic road section; $F C_{(i)}$ - fuel consumption of $i$-th vehicle categories per year on the $k$-th road section [litres apropos in kilograms]; $f_{F C}-$ correction factor of fuel

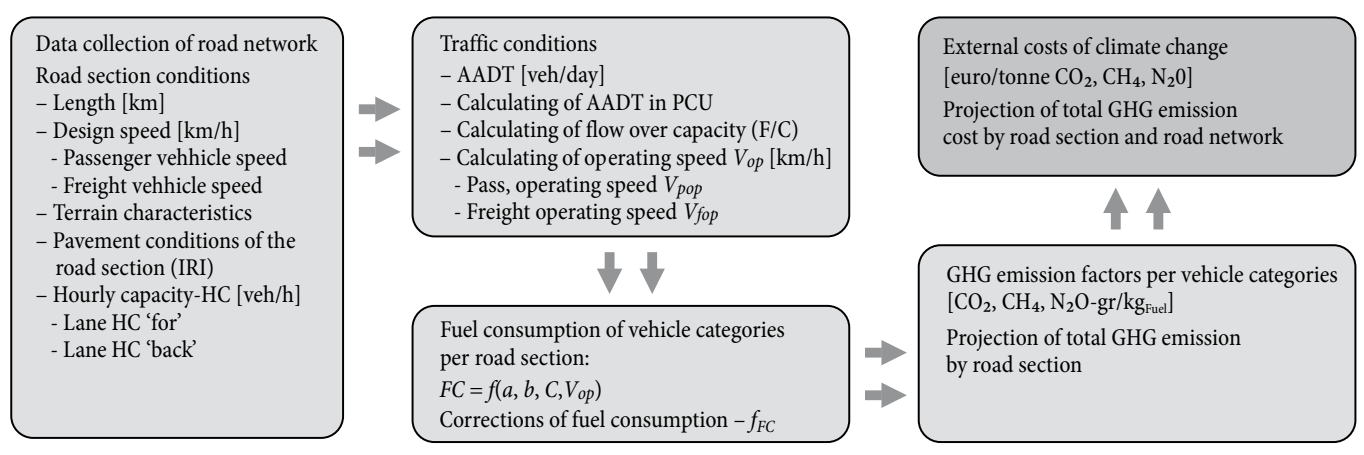

Fig. 1. Step approach to GHG emissions cost evaluation on the road network 
consumption (for passenger cars and freight vehicles); $E F_{\mathrm{GHG}(i, j)}$ - emission factors of $j$-th type of GHG for $i$-th vehicle category [grams GHG per kilograms of fuel]; $\mathrm{UCOST}_{\mathrm{GHG}(j)}$ - unit costs of $j$-th type of GHG [€ per tonne].

Data of road sections conditions and Annual Average Daily Traffic (AADT) data represent an input into the methodological step approach shown in Fig. 1, based on which it is possible to determine the operating speed on the $k$-th road section of the road network. Determination of operating speed is based on the Bureau of Public Roads (BPR) formula by which to determine the travel time on the road section, depending on different parameters that are relevant for a specific type of road section (Highway Capacity Manual 2000; Dell'Acqua et al. 2011). Fuel consumption of the $i$-th vehicle category on the $k$-th road section, per annum, is given by Eq. (2):

$$
\begin{aligned}
& F C_{(i)}=\operatorname{AADT}_{(i)} \cdot F C_{(i)}^{\prime} \cdot L_{(k)} \cdot 0.01 \cdot 365 \text { [litres apro- } \\
& \text { pos in kilograms], }
\end{aligned}
$$

where: $F C_{(i)}^{\prime}$ - average fuel consumption of the $i$-th vehicle category per $100 \mathrm{~km}$ of travel distance [litres $/ 100 \mathrm{~km}) ; L_{(k)}$ - length of the $k$-th road section $[\mathrm{km}]$.

The average fuel consumption of motor vehicles $F C_{(i)}^{\prime}$ is obtained by using HDM model. Based on the formed pairs 'fuel consumption-speed of the $i$-th vehicle categories' in the form of a polynomial of the second degree, it is obtained functional dependence of fuel consumption than the speed of the $i$-th motor vehicles categories, Eq. (3):

$$
F C_{(i)}^{\prime}=100 \cdot\left(a+b \cdot V_{o p}+c \cdot V_{o p}^{2}\right)_{(i)}[\text { lit } / 100 \mathrm{~km}],
$$

where: $a, b, c$ - regression parameters for characteristic terrain type and International Roughness Index (IRI) of the $i$-th road section.

Thus defined fuel consumption $F C_{(i)}$ does not take into consideration the mutual influence of vehicles in the traffic flow, so it needs to be corrected by using of correction factors $f_{F C}$. Values of correction factors of increasing fuel consumption due to the change at the design speed to operating speed, were obtained using the matrix of the speeds from the literature (Kuzović 1994). GHG emissions factors of motor vehicles $E F_{\mathrm{GHG}(i, j)}$ expressed in grams of GHG/kilograms of fuel, adopted on the basis of air pollutant emission inventory guidebook (EEA 2013; Domanovszky 2014) issued by the European Environment Agency. Maibach et al. (2008) recommend the following central values of unit costs of $\mathrm{CO}_{2}$ emission: for $2010-25 € /$ tonne $\mathrm{CO}_{2}$, for $2020-40$ $€ /$ tonne $\mathrm{CO}_{2}$, for 2030 - $55 € /$ tonne. Depending on year of research and forecasting of GHG emission costs in the future, interpolation method is possible to determine the costs of $\mathrm{CO}_{2}$ emission costs. Emission cost of $\mathrm{CH}_{4}$ and $\mathrm{N}_{2} \mathrm{O}$ are obtained based on Global Warming Potential (GWP) of $\mathrm{CH}_{4}$ and $\mathrm{N}_{2} \mathrm{O}$ compared to $\mathrm{CO}_{2}$, which are 25 and 298 respectively for a 100 -year perspective (IPCC 2007). That is, $U C O S T_{\mathrm{CH} 4}=U \operatorname{COST}_{\mathrm{CO} 2} \cdot 25 €$ and $U \operatorname{COST} T_{\mathrm{N} 2 \mathrm{O}}=U \operatorname{COST} T_{\mathrm{CO} 2} \cdot 298 €$.

On the other hand, $\mathrm{CO}_{2}$ emissions from the aviation have the most important influence on global climate caused by its longest atmospheric lifetime. From a macro perspective, the global aviation sector currently accounts for about $2 \%$ of the world $\mathrm{CO}_{2}$ emissions. For this reason, the most challenging task being undertaken by Committee on Aviation Environmental Protection (CAEP) is the development of the $\mathrm{CO}_{2}$ emissions certification standard for aircraft. The estimation of current and future progress toward the achievement of global environmental goals considering the $\mathrm{CO}_{2}$ trends was undertaken by CAEP. As depicted in Fig. 2 (ICAO 2013), it includes various categories of mitigation measures: aircraft-related technology development, improved air traffic management and infrastructure use, and alternative fuels, assuming that $1 \mathrm{~kg}$ of jet fuel burned generates $3.16 \mathrm{~kg}$ of $\mathrm{CO}_{2}$.

The aviation-related activities are sources of a variety of air pollutants that can have potentially negative impact on human health and the environment. Depend-

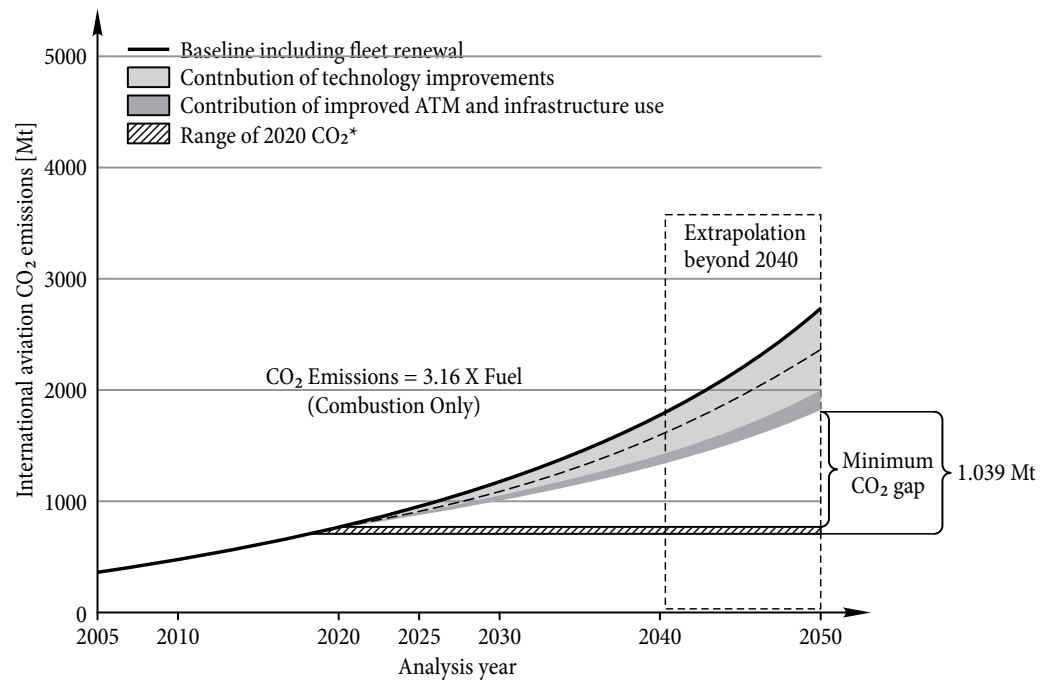

Fig. 2. $\mathrm{CO}_{2}$ emissions trends from international aviation (2005-2050) 
ing on the required level of accuracy and confidence of the results and availability of the supporting data, an emissions inventory at a given airport can be evaluated at the three different levels of complexity, i.e. by simple, advanced or sophisticated approach (ICAO 2011).

According to the Simple Approach, aircraft engine emissions can be estimated for all relevant emissions species $\left(\mathrm{CO}_{2}, \mathrm{HC}, \mathrm{NO}_{\mathrm{x}}, \mathrm{CO}\right.$ and $\left.\mathrm{SO}_{2}\right)$ using the following methodology proposed by ICAO. For each aircraft type, the number of Landing and Take-Off (LTO) cycles of that aircraft (over the assessment period) should be multiplied by the corresponding Emissions Factor (EF) for each of the pollutant species and then the values for all the aircraft should be added for obtaining the amount of total emissions $[\mathrm{kg}]$ for each pollutant (ICAO 2011) Eq. (4):

$$
\begin{aligned}
& \text { Emission of species } X_{[\mathrm{kg}]}= \\
& \sum_{\text {all aircraft }}(\text { Number of LTO cycles })_{\text {of aircraft } Y} \times \\
& (E F)_{\text {for species } X} .
\end{aligned}
$$

GHG emissions cost in air transport sector obtained by Eq. (5):

$$
\begin{aligned}
& \mathrm{GHGCOST}_{\text {Air }}=\frac{\text { Emission of species GHG }}{1000_{[\text {tonne }]}} \times \\
& \mathrm{UCOST}_{\text {GHG,Air }(j)}[€] .
\end{aligned}
$$

\section{Cost Estimation of GHG Emissions in Road and Air Transport Sector, Case Study of Serbia}

Based on the presented methodology, in this chapter estimation of GHG emissions cost in road and air transport sector in Serbia is conducted.

\subsection{Cost Estimation of GHG Emissions in Road Transport}

When collecting data about road sections conditions an updated database that was used for making a General master plan for transport in Serbia is used. The road network, which is investigating the GHG emissions costs in this paper, encompasses approximately $7000 \mathrm{~km}$ of roads of the Republic of Serbia: public roads of the IA, IB, II categories, and a smaller number of local road sections. Data of the AADT for each of the 302 road sections were obtained on the basis of traffic counting conducted by the Public Enterprise 'Roads of Serbia' for the year 2013 (Roads of Serbia 2014), so that the complete analysis of GHG emissions cost carried out in 2013.

For the calculation of operating speeds, following data are used: (Newton 2009): 1 bus $=1.75$ passenger car, 1 light truck $=1.50$ passenger car; 1 medium truck $=1.50$ passenger car; 1 heavy truck $=2.00$ passenger car; 1 articulated truck $=3.00$ passenger car.
Also, the coefficients $\alpha$ and $\beta$ are adopted according to (Newton 2009) and amounts for: motorway $(\alpha=0.45$, $\beta=4)$; urban road $(\alpha=0.5, \beta=2.5)$; rural road $(\alpha=0.8$, $\beta=1.5$ ).

The average fuel consumption of motor vehicles $F C_{(i)}^{\prime}$ are based on the Eq. 3. Regression parameters $a, b$ and $c$ for each vehicle category are taken from research (Ivković et al. 2011) and are given for a total of twelve combinations of terrain type and values of IRI for road sections (terrain type: flat, hilly, mountain; IRI: $2.5,8.12$ ).

Data of pollutant emission factors according to (EEA 2013) are given for the $21 \mathrm{EU}$ countries. The calculation of the average values of GHG emissions as a function of fuel consumption shows little difference between the 21 surveyed countries. The adopted values of average unit GHG emission factors are shown in Table 1.

Table 1. Unit GHG emission factors of motor vehicles [gr of GHG/kg of fuel]

\begin{tabular}{|l|c|c|c|}
\hline \multicolumn{1}{|c|}{ Vehicle category } & $\mathrm{N}_{2} \mathrm{O}$ & $\mathrm{CH}_{4}$ & $\mathrm{CO}_{2}$ \\
\hline Passenger car - gasoline & 0.206 & 0.71 & 3176 \\
\hline Passenger car - diesel & 0.087 & 0.06 & 3137 \\
\hline Passenger car - LPG & 0.089 & 0.32 & 3017 \\
\hline Bus & 0.050 & 0.41 & 3137 \\
\hline Light truck & 0.040 & 0.09 & 3137 \\
\hline Medium truck & 0.045 & 0.18 & 3137 \\
\hline Heavy truck & 0.051 & 0.27 & 3137 \\
\hline Articulated truck & 0.051 & 0.27 & 3137 \\
\hline
\end{tabular}

As the cost estimate of GHG emissions is done for the year 2013, adopted value of the unit emission cost of $\mathrm{CO}_{2}$ is obtained by interpolation relative to the values for 2010 and 2020, ie. $\mathrm{UCOST}_{\mathrm{CO} 2}=29.5 €$. Bearing in mind the GWP values for $\mathrm{CH}_{4}$ and $\mathrm{N}_{2} \mathrm{O}$ for a 100 year perspective, the adopted values of the unit emission costs of $\mathrm{CH}_{4}$ and $\mathrm{N}_{2} \mathrm{O}$ are $\mathrm{UCOST}_{\mathrm{CH} 4}=737.5 €$ and $\mathrm{UCOST}_{\mathrm{N} 2 \mathrm{O}}=8791 €$. Realized traffic volumes on the observed road network per vehicle categories are given in Table 2.

Table 3 shows the of GHG emission costs in the whole road network. The total value of GHG emission costs amounts to 68 million $€$.

As the volume of GHG emission costs of all vehicles categories affected by two key indicators which are realized traffic volume and unit GHG emission factors, in Fig. 3 are shown the specific GHG emission costs per $100 \mathrm{~km}$ travel distance of different vehicle category.

According to the Fig. 3, it can be concluded that the lowest cost per $100 \mathrm{~km}$ travel distance are typical for diesel passenger cars regarding of all three GHG $(0.000160$ $€ / 100 \mathrm{~km}$ for $\mathrm{CH}_{4} ; 0.002981 € / 100 \mathrm{~km}$ for $\mathrm{N}_{2} \mathrm{O} ; 0.360776$ $€ / 100 \mathrm{~km} \mathrm{CO}_{2}$ ).

Table 2. Realized traffic volumes on the observed road network $\left[\times 10^{6} \mathrm{veh} \cdot \mathrm{km}\right]$

\begin{tabular}{|c|c|c|c|c|c|c|c|c|c|c|}
\hline $\begin{array}{c}\text { Passenger } \\
\text { car }- \text { gasoline }\end{array}$ & $\begin{array}{c}\text { Passenger } \\
\text { car }- \text { diesel }\end{array}$ & $\begin{array}{c}\text { Passenger } \\
\text { car - LPG }\end{array}$ & Bus & $\begin{array}{c}\text { Total } \\
\text { Passengers }\end{array}$ & $\begin{array}{c}\text { Light } \\
\text { truck }\end{array}$ & $\begin{array}{c}\text { Medium } \\
\text { truck }\end{array}$ & $\begin{array}{c}\text { Heavy } \\
\text { truck }\end{array}$ & $\begin{array}{c}\text { Articulated } \\
\text { truck }\end{array}$ & $\begin{array}{c}\text { Total } \\
\text { freight }\end{array}$ & Total \\
\hline 2661 & 3757 & 1408 & 309 & 8136 & 127 & 352 & 555 & 749 & 1784 & 9921 \\
\hline
\end{tabular}


Table 3. Total GHG emission cost of different vehicle categories on the observed road network [€/year]

\begin{tabular}{|c|c|c|c|c|c|c|c|c|}
\hline & $\begin{array}{c}\text { Passenger } \\
\text { car-gasoline }\end{array}$ & $\begin{array}{c}\text { Passenger } \\
\text { car - diesel }\end{array}$ & $\begin{array}{c}\text { Passenger } \\
\text { car - LPG }\end{array}$ & Bus & $\begin{array}{c}\text { Light } \\
\text { truck }\end{array}$ & $\begin{array}{c}\text { Medium } \\
\text { truck }\end{array}$ & $\begin{array}{c}\text { Heavy } \\
\text { truck }\end{array}$ & $\begin{array}{c}\text { Articulated } \\
\text { truck }\end{array}$ \\
\hline $\mathrm{CH}_{4}$ & 57439 & 6018 & 15981 & 18662 & 940 & 5394 & 20332 & 36783 \\
\hline $\mathrm{CO}_{2}$ & 10222602 & 13554638 & 6026742 & 5642366 & 1256775 & 3755427 & 9567079 & 17308191 \\
\hline $\mathrm{N}_{2} \mathrm{O}$ & 197590 & 112023 & 52980 & 26971 & 4776 & 16054 & 46350 & 83854 \\
\hline
\end{tabular}

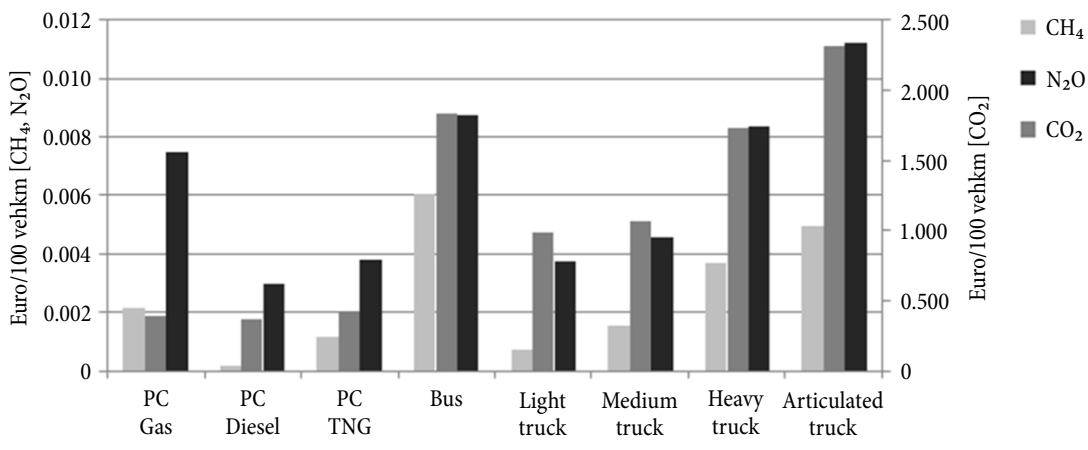

Fig. 3. Specific GHG emission cost per vehicle category

\subsection{Cost Estimation of GHG} Emissions in Air Transport

Table 4 summarizes the data regarding aircraft/engines combinations, i.e. fleet mix that operated at the Belgrade airport 'Nikola Tesla' on 1 February 2014, as well as the corresponding number of the LTO cycles. Additional information in conjunction with emissions factors for five pollutant species for each of the listed aircraft, together with associated fuel flow rates, are obtained from the ICAO Engine Emissions Databank (EASA 2015). Costs of pollutants are based on defined values set by Thomson Reuters Point Carbon from June 2013. This paper presents base values, which were calculated using the average prices. (EUROCONTROL 2015) recommended values are provided for $\mathrm{CO}_{2}$ and air pollution emissions. For monitored year, obtained results are provided in table 4 (for example, $4.4 € /$ tonne $\mathrm{CO}_{2} ; 4.5 € / \mathrm{kg} \mathrm{NO}$, etc.).
The results of applying the abovementioned equation to the considered case of Belgrade airport on a given day is presented in Fig. 4. This figure shows distribution of the emissions values for each of the pollutant species by aircraft type and the total values for each of the pollutant species emitted during one day operations at Belgrade airport, respectively. As it can be seen from this figure, engine emissions from aircraft Airbus A319 mostly influence the local air quality in the airport vicinity. However, this result was expected, bearing in mind the dominance of this aircraft type at the airport, which is also a novelty in the fleet of the national airline.

According to data on emissions of pollutants by 27 different aircraft (Rypdal 2002) and taking into account the GWP of $\mathrm{CH}_{4}$ and $\mathrm{N}_{2} \mathrm{O}$ we can conclude that their share in total costs of GHG emissions are less than $2.5 \%$. For this reason, these species of GHG were not considered.

Table 4. Aircraft engine emissions

\begin{tabular}{|c|c|c|c|c|c|c|c|c|}
\hline \multirow{2}{*}{ Aircraft type } & \multirow{2}{*}{ Engine type } & \multicolumn{5}{|c|}{ LTO Emissions factors/airplane [kg/LTO/aircraft] } & \multirow{2}{*}{$\begin{array}{c}\text { Fuel consumption } \\
{[\mathrm{kg} / \mathrm{LTO} /} \\
\text { aircraft }]\end{array}$} & \multirow{2}{*}{$\begin{array}{c}\text { Number of LTO } \\
\text { cycles (1 February } \\
2014)\end{array}$} \\
\hline & & $\mathrm{CO}_{2}$ & $\mathrm{HC}$ & $\mathrm{NO}_{\mathrm{x}}$ & $\mathrm{CO}$ & $\mathrm{SO}_{2}$ & & \\
\hline A319 & CFM56-5A5 & 1153.4 & 0.297 & 4.367 & 3.175 & 0.365 & 365 & 20 \\
\hline B737-300 & CFM56-3-B1 & 1238.72 & 0.418 & 3.595 & 6.517 & 0.39 & 392 & 11 \\
\hline ATR72 & PW127F & 310 & 0.145 & 0.91 & 1.165 & 0.1 & 100 & 9 \\
\hline Embraer 195 & CF34-10E5 & 957.48 & 0.848 & 2.836 & 6.761 & 0.155 & 303 & 4 \\
\hline B737-800 & CFM56-7B26 & 1393.56 & 0.361 & 6.149 & 3.533 & 0.44 & 441 & 2 \\
\hline Fokker 100 & TAY Mk650-15 & 1194.48 & 0.717 & 2.875 & 6.921 & 0.38 & 378 & 1 \\
\hline A320 & CFM56-5-A1 & 1216.6 & 0.285 & 4.506 & 3.093 & 0.385 & 385 & 9 \\
\hline Embraer 175 & CF34-8E5 & 761.56 & 0.018 & 2.222 & 2.065 & 0.155 & 241 & 1 \\
\hline Embraer 190 & CF34-10E5 & 957.48 & 0.848 & 2.836 & 6.761 & 0.155 & 303 & 2 \\
\hline Bombardier Q400 & PW120 & 320 & 0 & 0.755 & 1.12 & 0.1 & 100 & 1 \\
\hline
\end{tabular}




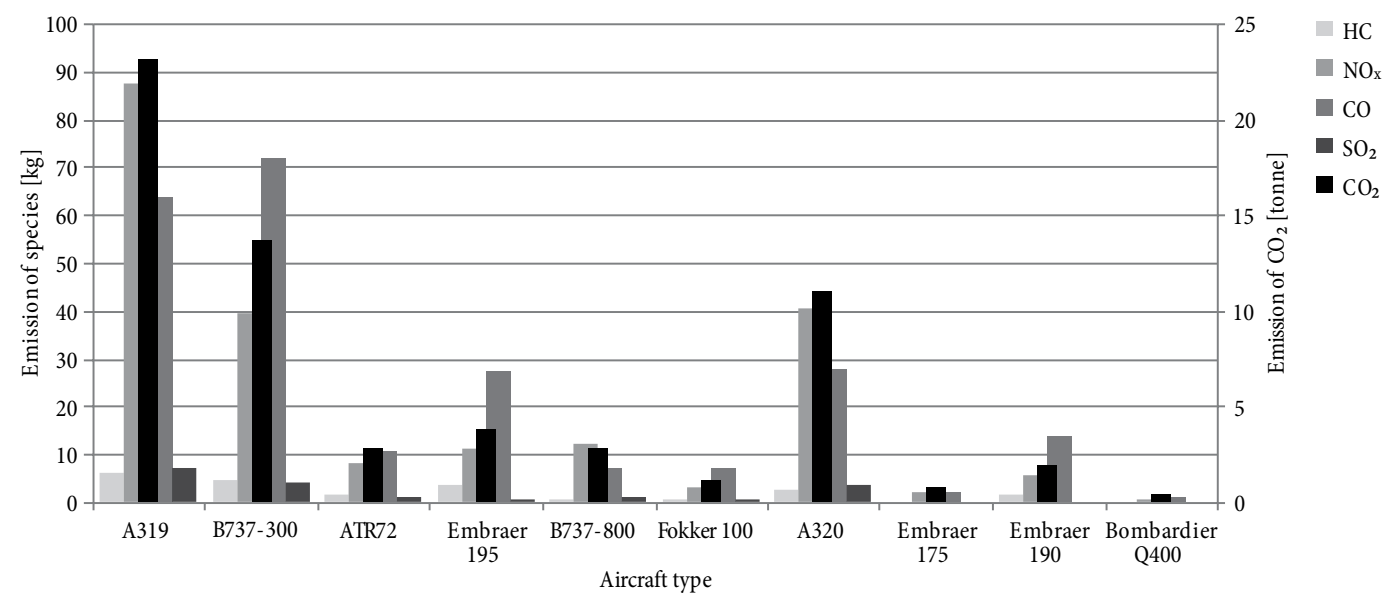

Fig. 4. Distribution of the LTO emissions factors by aircraft type

Table 5 shows $\mathrm{CO}_{2}$ emission costs for different aircraft types.

Analysing the achieved daily traffic expressed in LTO cycles at Belgrade airport 'Nikola Tesla' we can notice that the A319 aircraft are the largest source of $\mathrm{CO}_{2}$ emissions costs. The reasons are twofold: first, high level of LTO emission factor for $\mathrm{CO}_{2}$ and second, largest number of LTO cycles.

Table 5. $\mathrm{CO}_{2}$ emission costs for different aircraft types

\begin{tabular}{|l|l|c|}
\hline Aircraft type & Engine type & $\begin{array}{c}\text { Emission cost of } \mathrm{CO}_{2} \\
\text { for total } \\
\text { LTO for 1 February 2014 [€] }\end{array}$ \\
\hline A319 & CFM56-5A5 & 101.50 \\
\hline B737-300 & CFM56-3-B1 & 59.95 \\
\hline ATR72 & PW127F & 12.28 \\
\hline Embraer 195 & CF34-10E5 & 16.85 \\
\hline B737-800 & CFM56-7B26 & 12.26 \\
\hline Fokker 100 & TAY Mk650-15 & 5.26 \\
\hline A320 & CFM56-5-A1 & 48.18 \\
\hline Embraer 175 & CF34-8E5 & 3.35 \\
\hline Embraer 190 & CF34-10E5 & 8.43 \\
\hline $\begin{array}{l}\text { Bombardier } \\
\text { Q400 }\end{array}$ & PW120 & 1.41 \\
\hline
\end{tabular}

\section{Conclusions}

The conclusions of this research are as follows:

- The main source of GHG emissions in the transport sector of the Republic of Serbia is road transport mode. This is in the line with the current situation and trends in the EU. The total cost of GHG emissions of passenger vehicles at the level of long distance transport amounts to 36 million $€$. One of the causes of this situation is the average vehicle age of 16 years (RTSA 2015). Therefore, road transport gives the greatest opportunities for reducing of negative environment effects using various technological, economic, planning and other mitigation measures.

- Methodology presented in the paper (especially in road transport mode) takes into account the differ- ent road and traffic conditions of individual road sections such as: terrain type, IRI, the number of lanes on the carriageway direction, hourly capacity of the road sections, mutual influence of vehicles in the traffic flow, operating speed. In addition to conventional road vehicles, with determination of the relevant fuel equivalent, this methodology could be applied to new technical and technological solutions of road vehicles.

- The methodology used in the air transport sector allows the assessment of costs of GHG emissions taking into account the number of LTO cycles and emission factors specific for aircraft types.

- The paper shows that in road and air transport sector, $\mathrm{CO}_{2}$ has a dominant contribution in total costs of GHG emissions (about 98\%).

- Of all vehicles categories, passenger cars have the biggest share of the GHG emission costs (53\%), of which the largest share is typical for diesel cars (38\%) due to the largest realized traffic volume. The buses have the lowest contribution (16\%). In the case of freight vehicles, largest GHG emission costs are typical for articulated trucks (54\% of all commercial vehicles).

- The lowest cost per $100 \mathrm{~km}$ travel distance are typical for diesel passenger cars regarding of all three GHG $\left(0.000160 € / 100 \mathrm{~km}\right.$ for $\mathrm{CH}_{4} ; 0.002981 € / 100 \mathrm{~km}$ for $\mathrm{N}_{2} \mathrm{O} ; 0.360776 € / 100 \mathrm{~km}$ for $\mathrm{CO}_{2}$ ). The highest value of specific GHG emission costs have articulated trucks for $\mathrm{N}_{2} \mathrm{O}(0.011187 € / 100 \mathrm{~km})$ and $\mathrm{CO}_{2}$ $(2.309087 € / 100 \mathrm{~km})$. For gasoline passenger cars is characteristic the bigger deviation of $\mathrm{N}_{2} \mathrm{O}$ emission cost to $\mathrm{CH}_{4}$ and $\mathrm{CO}_{2}$ emission costs by observing the equivalent variations in the case of other vehicle categories. - On the main hub point in the Serbia, Belgrade airport 'Nikola Tesla', total daily traffic amounted to 60 LTO cycles. Over $80 \%$ of the total daily traffic refers to only 4 aircraft types (A319, B737-300, ATR72, A320) among which A319 aircraft recorded highest percent ( 33\%). - According to presented traffic volume, the total daily costs of $\mathrm{CO}_{2}$ emissions amounted to nearly $270 €$. These costs would be 7 times higher if the adopted unit costs of $\mathrm{CO}_{2}$ emissions applied from the road transport sector. A319 aircraft is the largest sources of these costs, with share of almost $38 \%$. 


\section{Acknowledgements}

This paper is based on the project 'Software development and national database for strategic management and development of transportation means and infrastructure in road, rail, air and inland waterways transport using the European transport network models', No TR36027, 20112015, financed by the Ministry of Education, Science and Technological Development of the Republic of Serbia.

\section{References}

Alonso, G.; Benito, A.; Lonza, L.; Kousoulidou, M. 2014. Investigations on the distribution of air transport traffic and $\mathrm{CO}_{2}$ emissions within the European Union, Journal of Air Transport Management 36: 85-93.

http://dx.doi.org/10.1016/j.jairtraman.2013.12.019

Andrejszki, T.; Gangonells, M.; Molnar, E.; Török, Á. 2014a. ForFITS: a new help in transport decision making for a sustainable future, Periodica Polytechnica - Transportation Engineering 42(2): 119-124.

http://dx.doi.org/10.3311/PPtr.7442

Andrejszki, T.; Török, Á.; Molnar, E. 2014b. The long-term forecast of land passenger transport related $\mathrm{CO}_{2}$ emission and energy use in Hungary, International Journal for Traffic and Transport Engineering 4(4): 386-396.

http://dx.doi.org/10.7708/ijtte.2014.4(4).03

Arul, S. G. 2014. Methodologies to monetize the variations in load factor and GHG emissions per passenger-mile of airlines, Transportation Research Part D: Transport and Environment 32: 411-420.

http://dx.doi.org/10.1016/j.trd.2014.08.018

Bakker, S.; Huizenga, C. 2010. Making climate instruments work for sustainable transport in developing countries, Natural Resources Forum 34(4): 314-326. http://dx.doi.org/10.1111/j.1477-8947.2010.01315.x

Batista, T.; Freire, F.; Silva, C. M. 2015. Vehicle environmental rating methodologies: overview and application to lightduty vehicles, Renewable and Sustainable Energy Reviews 45: 192-206. http://dx.doi.org/10.1016/j.rser.2015.01.040

Bickert, S.; Kampker, A.; Greger, D. 2015. Developments of $\mathrm{CO}_{2}$-emissions and costs for small electric and combustion engine vehicles in Germany, Transportation Research Part D: Transport and Environment 36: 138-151. http://dx.doi.org/10.1016/j.trd.2015.02.004

Chavez-Baeza, C.; Sheinbaum-Pardo, C. 2014. Sustainable passenger road transport scenarios to reduce fuel consumption, air pollutants and GHG (greenhouse gas) emissions in the Mexico City metropolitan area, Energy 66: 624-634. http://dx.doi.org/10.1016/j.energy.2013.12.047

Dell'Acqua, G.; De Luca, M.; Mauro, R. 2011. Road safety knowledge-based decision support system, Procedia - Social and Behavioral Sciences 20: 973-983.

http://dx.doi.org/10.1016/j.sbspro.2011.08.106

Domanovszky, H. 2014. Gas propulsion or e-mobility is the solution on the way of clean and carbon free road transportation?, Periodica Polytechnica - Transportation Engineering 42(1): 63-72. http://dx.doi.org/10.3311/PPtr.7254

EASA. 2015. ICAO Aircraft Engine Emissions Databank. European Aviation Safety Agency (EASA). Available from Internet: http://www.easa.europa.eu/document-library/ icao-aircraft-engine-emissions-databank

EEA. 2014. Focusing on Environmental Pressures from Long-Distance Transport - TERM 2014: Transport Indicators Track- ing Progress Towards Environmental Targets in Europe. EEA Report No 7/2014. European Environment Agency (EEA). Available from Internet: http://www.eea.europa.eu/publications/term-report-2014

EEA. 2013. EMEP/EEA Air Pollutant Emission Inventory Guidebook - 2013: Technical Guidance to Prepare National Emission Inventories. EEA Technical report No 12/2013. European Environment Agency (EEA). Available from Internet: http://www.eea.europa.eu/publications/emep-eeaguidebook-2013

EUROCONTROL. 2015. Standard Inputs for EUROCONTROL Cost-Benefit Analyses. European Organisation for the Safety of Air Navigation (EUROCONTROL). 108 p. Available from Internet: https://www.eurocontrol.int/sites/default/ files/publication/files/standard-input-for-eurocontrol-costbenefit-analyses-2015.pdf

Galanis, A.; Eliou, N. 2014. How future technology in road transportation could create a more sustainable built environment?, in ICTTE Belgrade 2014: Proceedings of the Second International Conference on Traffic and Transport Engineering, 27-28 November 2014, Belgrade, Serbia, 512-516.

Hao, H.; Geng, Y.; Li, W.; Guo, B. 2015. Energy consumption and GHG emissions from China's freight transport sector: Scenarios through 2050, Energy Policy 85: 94-101. http://dx.doi.org/10.1016/j.enpol.2015.05.016

Highway Capacity Manual. 2000. Transportation Research Board. $1134 \mathrm{p}$.

ICAO. 2013. Environmental Report 2013: Aviation and Climate Change. International Civil Aviation Organization (ICAO). 224 p. Available from Internet: http://cfapp.icao.int/Environmental-Report-2013/files/assets/common/downloads/ ICAO_2013_Environmental_Report.pdf

ICAO. 2011. Airport Air Quality Manual. Doc 9889. International Civil Aviation Organization (ICAO). 200 p. Available from Internet: http://www.icao.int/publications/Documents/9889_cons_en.pdf

IEA. 2012. $\mathrm{CO}_{2}$ Emissions from Fuel Combustion. Beyond 2020 Online Database. 2012 Edition. International Energy Agency (IEA). Available from Internet: http://www.iea.org/ statistics/topics/CO2emissions

IPCC. 2013. Climate Change 2013: The Physical Science Basis. IPCC Working Group I Contribution to AR5. Intergovernmental Panel on Climate Change (IPCC). Available from Internet: http://www.climatechange2013.org

IPCC. 2007. Climate Change 2007: Synthesis Report. IPCC Fourth Assessment Report (AR4). Intergovernmental Panel on Climate Change (IPCC). Available from Internet: https://www.ipcc.ch/publications_and_data/publications_ ipcc_fourth_assessment_report_synthesis_report.htm

Ivković, I.; Janjoš, Ž.; Žeželj, S.; Jovanović, V. 2011. Research into the costs of vehicle exhaust gases from the standpoint of using natural gas-powered buses, African Journal of Business Management 5(22): 9304-9321.

JRC/PBL. 2013. Global Emissions EDGAR v4.2 FT2010. Joint Research Centre (JRC) and the Netherlands Environmental Assessment Agency (PBL). Available from Internet: http:// edgar.jrc.ec.europa.eu/overview.php?v=42FT2010

Kaplanović, S.; Mijailović, R. 2012. The internalisation of external costs of $\mathrm{CO}_{2}$ and pollutant emissions from passenger cars, Technological and Economic Development of Economy 18(3): 470-486.

http://dx.doi.org/10.3846/20294913.2012.702694

Kuzović, L. 1994. Vrednovanje u upravljanju razvojem i eksploatacijom putne mreže. Beograd: Saobraćajni fakultet. 274 p. (in Serbian). 
Loo, B. P. Y.; Li, L.; Psaraki, V.; Pagoni, I. 2014. $\mathrm{CO}_{2}$ emissions associated with hubbing activities in air transport: an international comparison, Journal of Transport Geography 34: 185-193. http://dx.doi.org/10.1016/j.jtrangeo.2013.12.006

Maibach, M.; Schreyer, C.; Sutter, D.; Van Essen, H. P.; Boon, B. H.; Smokers, R.; Schroten, A.; Doll, C.; Pawlowska, B.; Bak, M. 2008. Handbook on Estimation of External Costs in the Transport Sector. CE Delft. 336 p. Available from Internet: http://ec.europa.eu/transport/themes/sustainable/doc/2008_costs_handbook.pdf

Nešić, A.; Čavka, I.; Čokorilo, O. 2015. Shifting to more environmentally friendly modes in long-distance transport, in Proceedings of the 2nd International Academic Conference of Places and Technologies, 18-19 June 2015, Nova Gorica, Slovenia, 1-6.

Newton, S. 2009. Serbian National Transport Model System. Zoetermeer. $54 \mathrm{p}$.

Peng, B.; Du, H.; Ma, S.; Fan, Y.; Broadstock, D. C. 2015 Urban passenger transport energy saving and emission reduction potential: a case study for Tianjin, China, Energy Conversion and Management 102: 4-16.

http://dx.doi.org/10.1016/j.enconman.2015.01.017

Roads of Serbia. 2014. Public roads of the IA, IB, II Categories in the Republic of Serbia - Average Annual Daily Traffic $A A D T$ in 2013. Public Enterprise 'Roads of Serbia'. Available from Internet: http://www.putevi-srbije.rs

RTSA. 2015. Statistical Data. RTSA (Road Traffic Safety Agency) of the Republic of Serbia. Available from Internet: http://en.abs.gov.rs

Rypdal, K. 2002. Aircraft emissions, in Background Papers: IPCC Expert Meetings on Good Practice Guidance and Uncertainty Management in National Greenhouse Gas Inventories. Institute for Global Environmental Strategies (IGES), 93-102. Available from Internet: http://www.ipcc-nggip. iges.or.jp/public/gp/gpg-bgp.html

Török, Á. 2014. Environmental comparism of road and railway transport: a case study in Hungary, International Journal for Traffic and Transport Engineering 4(2): 210-219. http://dx.doi.org/10.7708/ijtte.2014.4(2).07

Török, Á.; Török, A.; Heinitz, F. 2014. Usage of production functions in the comparative analysis of transport related fuel consumption, Transport and Telecommunication 15(4): 292-298. http://dx.doi.org/10.2478/ttj-2014-0025

Yan, X.; Crookes, R. J. 2009. Reduction potentials of energy demand and GHG emissions in China's road transport sector, Energy Policy 37(2): 658-668.

http://dx.doi.org/10.1016/j.enpol.2008.10.008 